\title{
Quality of Potable Water Available to the Residents of Anambra State, Nigeria
}

\section{Chigozie John Onyinye Anarado, Charity Ebere Anarado* (1), Benjamin Chimezie Izuagbachukwu, Uzorchukwu Michael Ogu, Amarachi Maduka, Chinyelu Ijeamaka Egwuatu, Valentine Ifenna Onwukeme}

Department of Pure and Industrial Chemistry Nnamdi Azikiwe University, Awka, Anambra State, Nigeria

Email: cjo.anarado@unizik.edu.ng, ‘ce.anarado@unizik.edu.ng, izuagbachukwub@gmail.com,

talk2micheal4real_luv@yahoo.com, amarachimaduka00@gmail.com,ci.egwuatu@unizik.edu.ng, vi.onwukeme@unizik.edu.ng

How to cite this paper: Anarado, C.J.O., Anarado, C.E., Izuagbachukwu, B.C., Ogu, U.M., Maduka, A., Egwuatu, C.I. and Onwukeme, V.I. (2019) Quality of Potable Water Available to the Residents of Anambra State, Nigeria. Natural Resources, 10, 395-414.

https://doi.org/10.4236/nr.2019.1011027

Received: September 24, 2019

Accepted: November 23, 2019

Published: November 26, 2019

Copyright $\odot 2019$ by author(s) and Scientific Research Publishing Inc. This work is licensed under the Creative Commons Attribution International License (CC BY 4.0).

http://creativecommons.org/licenses/by/4.0/

\begin{abstract}
Public pipe-borne water system had collapsed in Anambra state of Nigeria, for over fifteen years, challenging the residents of the state to resort to alternative sources of potable water, notably, boreholes. It is imperative to continuously assess the quality of the water. In this work, two boreholes each in nineteen communities, one from Aguluzigbo, in three local government areas (Anaocha, Awka-North, Awka-South) in the state were sampled, and tested for $\mathrm{pH}$, Conductivity, Hardness, Total Suspended Solids, Lead, Arsenic, Cadmium, Bacteria and Yeast loads. The water samples were all soft and mostly acidic. While there were not much threats of yeast, the aerobic bacteria counts were above the acceptable limits. The Lead, Arsenic and Cadmium concentrations were above the tolerable limits in most communities in Anaocha and Awka-South. Arsenic, Lead, Cadmium were absent in all the samples in Awka-North except in four communities where Cadmium was present. Suspended solid contents were also high in all the Local Government Areas. Overall, the quality of the water consumed by the people in the selected population calls to question of the water and sanitation component of the public health system.
\end{abstract}

\section{Keywords}

Potable Water, Cadmium, Lead, Arsenic, pH, Bacteria Load, Total Suspended Solids, Conductivity, Hardness

\section{Introduction}

Water is a renewable resource and exists in a continuous state flux, the balance is governed by conservation of mass, and all land areas in a river basin are inter- 
linked through water [1]. Water, the source of life and human civilization, has become one of the major issues in recent years. It is probably the most valuable natural resource available to man, and no doubt the most essential element to human without which no life can survive. Not only is water essential to every single cell and organ in the body, it makes up two-thirds of the weight of the human body and plays a very vital role in existence as well as maintenance of life of organisms [2] [3] [4]. Even though water covers $78 \%$ of the earth's surface, yet water available for human use is limited [5]. Without doubts, the much desired dream of all human beings having easy access to safe and affordable potable (drinking) water is generally considered by many as one of the most basics of all human rights, and should nonetheless assume the status of one of the critical drivers of any effectively planned and properly implemented human health protection and development policy framework-be it local, state, regional, national or global [6] [7] [8] [9]. Global water use has been growing at more than twice the rate of population increase in the last century due to population growth and the demands of irrigated agriculture, and although there is no global water scarcity as such, an increasing number of regions are chronically short of water [10] [11]. It is also a fact that water availability will continue to be a contributing factor to migration, particularly in those regions where compounding factors of poverty and vulnerability to natural hazards are present [12]. It was estimated that every year, millions of people die from a lack of clean, fresh drinking water. Beyond a few scientific journals and United Nations' ("UN") summit publications, major media outlets choose to ignore these staggering figures, focusing their scientific reporting instead on the impending obsolescence of fossil fuels. Water is an essential, life-giving force; its scarcity demands our attention [13].

In the last century, the world population has tripled. It is expected to rise from the present 6.5 billion to 8.9 billion by 2050, before leveling off. Currently half of the world's population lives in cities, and by 2030, this figure will grow to $60 \%$, most notably in Africa and Asia where urban populations are predicted to double between the years 2000 and 2030. Today, urban dwellers in certain developing cities in Africa pay 5 to 7 times more for water than the average price paid in the United States or Europe [14]. At the beginning of 19th century drinking water in urban areas was available with little or no purification needed, but growing industrialization and urbanization led to increased pollution and occurrence of faecal-borne diseases [15]. The World Health Organization (WHO) estimates that almost $10 \%$ of the population in the world do not have access to improved drinking water sources, and one of the United Nations (UN) Sustainable Development Goals is to ensure universal access to water and sanitation by 2030 [16]. In recent years, water sector professionals have made considerable progress improving access to drinking water worldwide. The Millennium Development Goal (MDG) for drinking water was met in 2015, with 2.6 billion people gaining access to an improved drinking water source since 1990 [17]. Although progress has been made in supplying drinking water to more people year on year, 663 million people still lack "improved" drinking water 
sources in 2015 and for many people, this "improved" water is not always safe, reliable, affordable or accessible with equity [18]. According to the World Health Organization/United Nations International Children's Emergency Fund (WHO/UNICEF) 2017 and 2019, billions of people around the world are continuing to suffer from poor access to safely managed drinking water services, sanitation and hygiene and 1 in 3 people globally do not have access to safe drinking water [19] [20]. Providing safe drinking water is paramount for public health to prevent water-related diseases. Though, the "Water for Life" International Decade for Action 2005-2015 which was said to have helped around 1.3 billion people in developing countries gain access to safe drinking water, monitoring and maintaining water safety in piped systems and point sources around the world is still challenging [21] [22] [23] [24]. It has also been reported that nearly 2 million people suffer devastating waterborne diseases on an annual basis, and these even result in high mortality for certain cases [25].

Africa is the second-driest continent in the world, after Australia, and suffers from acute water scarcity problems that involve water stress, water deficit/shortage and water crisis [26]. In Africa, Water quality testing is not performed as often as is necessary, and lack of education among the people utilizing the water source leads them to believe that as long as they are getting water from a well, it is safe. Once a source of water has been provided, quantity of water is often given more attention than quality of water [27]. According to WHO, less than 50\% of people in rural Africa have access to both improved drinking water and sanitation and more than $50 \%$ of the 663 million people Worldwide who lack access to safe water reside in Sub-Saharan Africa, where over $40 \%$ of all people are still without improved drinking water [28] [29]. [30]. Also According to Mukuhlani and Nyamupingidza 2014, at least $25 \%$ of countries in Africa are already experiencing water pressure; another 11 countries are expected to join them by 2025 at which time nearly 50 per cent of Africa's predicted population of 1.45 billion people will face water stress or scarcity. Nearly half of the population (300 million people) in sub-Saharan countries lack access to a supply of safe water and 41 per cent lack adequate sanitation [31]. Africa is certainly not on track to meet the Millennium Development Goal for drinking water and sanitation. Rather, it is headed to a continuous, endemic water and sanitation crisis that debilitates and kills huge numbers of people, threatens the health of the workforce, stands in the way of economic growth and limits access to education and, therefore, life opportunities. Every year, it is estimated that more than half of Africans have water-related diseases and one million Africans die from diseases related to unsafe drinking water, poor sanitation and poor hygiene, and between $1 \%$ to $2.5 \%$ of GDP of African countries and $\$ 5.5$ billion are lost annually due to inadequate sanitation [32] [33].

Nigeria is blessed with abundant water resources but largely untapped. In spite of the abundant water resources, government at all levels (federal, state and local) have not been able to successfully harness these resources to ensure a sustainable and equitable access to safe, adequate, improved and affordable wa- 
ter supply and sanitation to its population [34]. As one of the fastest urbanizing country in the continent, the rate of urbanization in Nigeria is characterized by high population concentration, increase in industrial, agricultural activities and indiscriminate disposal of all kinds of wastes, which are perceived to pose serious pollution threats with all its concomitant health hazards on groundwater quality especially in urban areas [35] [36] [37].

The quality of any body of surface or ground water is a function of either or both natural influences and human activities [38]. Drinking water based on groundwater resources contains geogenic elements which may be important long-term exposures to humans and may result in both harmful (e.g., arsenic) or beneficial (e.g., magnesium and calcium) health effects [39]. Also Climate Change is not just an energy problem because the incursion of storms and the loss of coast may cause drinking water supplies to be contaminated with salt water. Paradoxically, climate change prevention through carbon sequestration may also risk contaminating drinking water, and risk of waterborne diseases such as diarrhea, cholera, skin and eye diseases. Also increasing changes in precipitation patterns resulting from Climate change are likely to compromise the supply and quality of water through floods and water logging [40] [41].

Various researchers have studied the quality of many samples of water, example Babič et al., 2017 monitored microbiological drinking water safety by bacterial parameters and discovered faecal contamination and the parameters correlate with gastro-intestinal illness [42]. In 2015 Babic et al., also studied Yeasts and yeast-like fungi in tap water and groundwater, and their transmission to household appliances and discovered that all 116 water samples sampled showed presence of selected culturable fungi with emphasis on human opportunistic pathogenic species [43]. Ayanbimpe et al., 2012 analyzed 150 water samples in Jos, Nigeria and the result showed that $53.3 \%$ of the samples were contaminated with fungi [44]. Also many other researchers have reported the outbreak of diseases resulting from the use of unsafe water example, according to Chaminuka and Nyatsanza 2013, in many African countries, people still die of water related illnesses example Zimbabwe experienced a cholera outbreak in 2009 and the principal cause of the outbreak was the lack of access to safe water in urban areas and communities [45]. According to Kandji, (2006), 80\% of Kenyans continue to have inadequate access to water, drink unsafe water (the water is from unreliable sources), and spend much time and money trying to acquire it. As a result, most people suffer and die due to water related issues such as waterborne diseases (diarrhoea, dysentery or cholera) mostly from consumption of untreated water, which account for $60 \%$ of all diseases in Kenya [46]. Jidauna et al., 2017 assessed some domestic water sources in Dutsinma town, Kastina State. The result indicated that water from tap water was acidic and the concentration of lead was above WHO standard [47]. In Nigeria, 2010, a cholera epidemic was reported which claimed the lives of about 431 persons in 11 states [48]. Ohwo and Abotutu, 2014 assessed potable water supply in Yenagoa Metropolis, in Nigeria and discovered that the level of turbidity, lead, iron were above WHO thresholds, 
and the samples were found to be acidic [49].

Some Heavy metals such as lead, cadmium and arsenic are among the hazardous toxins around us [50]. The three metals, lead, mercury and cadmium, and the metalloid arsenic have all caused major human health problems in various parts of the world [51]. Chronic exposure to high levels of arsenic, cadmium, and other toxic metals has also been associated with higher risk of cancers of the bladder, kidney, liver, lung, and skin. Emerging evidence suggests that these toxic metals may have adverse effects on these outcomes even at lower concentrations [52]. Water is life, determination of quality of potable water is very important because this determines the health of man.

\section{Methods}

\subsection{Sample Location}

Anambra State Located in the South East Geopolitical zone of Nigeria is traversed by many rivers of national and regional importance which include: the river Niger, Anambra, Mamu, Idemili etc, With a population of 4,182,032 million people, spread over a land mass of $44,116 \mathrm{~km}^{2}$; Anambra State in the Federal Republic of Nigeria is the most densely populated state in the southeastern part of the country. The state lies between latitude $5^{\circ} 42^{\prime} \mathrm{N}$ and $6^{\circ} 47^{\prime} \mathrm{N}$ and longitude $6^{\circ} 37^{\prime} \mathrm{E}$ and $7^{\circ} 23^{\prime} \mathrm{E}$, being made up of 127 communities divided into 22 Local Government Areas. Anambra State lies within the humid tropical rainforest belt of Nigeria with an annual rainfall of about $2000-3000 \mathrm{~mm}$, annual mean minimum temperature is about $23^{\circ} \mathrm{C}$ while the annual mean maximum temperature is about $32^{\circ} \mathrm{C}$, and mean annual sunshine hours of about 1750 hours. Relative humidity varies with season with an average value of about $75 \%-95 \%$ and a mean annual atmospheric pressure of about $1101 \pm 1.2 \mathrm{~m}$ bars [53] [54] [55]. Awka South is located between latitudes $6^{\circ} 10^{\prime} \mathrm{N}$ and $6^{\circ} 15^{\prime} \mathrm{N}$ and longitudes $7^{\circ} 2^{\prime} 30^{\prime} \mathrm{E}$ and $7^{\circ} 7^{\prime} 30^{\prime} \mathrm{E}$ on the South eastern part of Nigeria. The study area covers 144.5 ha with a 2006 contested population of 116, 208 persons [56]. Anaocha local government area is one of the twenty one Local Government Areas that make up the present Anambra State, Nigeria. It is a rural Local Government Area with its headquarter at Neni. Anaocha spans over 171.62 kilometres with a population of 284,215 based on the 2006 Census. The major occupation of the people of Anaocha is farming, followed by trading and civil service [57]. Awka North Local Government Area of Anambra State, Nigeria. It is located at latitude 60151 $\mathrm{N}$ and $70101 \mathrm{E}$ and longitude $6.2500 \mathrm{~N}$ and $7.1670 \mathrm{E}$. It occupies a total land area of 340 square kilometers, with a population of 112,608 people [58].

\subsection{Sample Collection and Analyses}

Thirty nine borehole water samples were collected, two boreholes each in nineteen communities: AM1-Eke Amawbia, AM2-St Matthew Amawbia, UM1- Enugu Umuawulu, UM2-St Joseph Umuawulu, NB1-Eke Nibo, NB2-GMG Nibo, NS1-Ngodo Nise, NS2-St John Nise, MB1-St Dominic Mbaukwu, MB2-Akabor 
Mbaukwu, OK1-Y junction Okpuno, OK2-Boulevard Okpuno, EZ1-Ndikpa Ezinato, EZ2-Ndiora Ezinato (Figure 1), AD1-Alor Road Adazi Ani, AD2-Eke Adazi Ani, AN1-Bubendof Adazi Nnukwu, AN2-Nkwoagu Adazi Nnukwu, AG1-Nkitaku Agulu, AG2-Okpu Agulu, AZ1-Ifite Aguluzigbo, NN1-Umueri Neni, NN2-Umueze Neni, NR1-Agbadani Nri, NR2-Iruoforo Nri, OB1-Iruowelle Obeledu, OB2-Obeledu Ani Obeledu (Figure 2), AS1-Igbagu Amansea, AS2-Umuokpara Amansea, AK1-Amaeze Amanuke, AK2-Eziama Amanuke, EB1-Amagu Ebenebe, EB2-Umuji Ebenebe, UR1-Umuife Urum, UR2-Ativ Urum, IS1-Ifite-isu Isuaniocha, IS2-Ofiakuz Isuaniocha, MG1-Amaezike Mgbakwu, MG2-Uruonage in three local government areas (Awka-South, Anaocha and Awka-North,) in Anambra State (Figure 3). One sample was collected from Aguluzigbo AZ1, because it was the only functional borehole from the community at the time of collection.

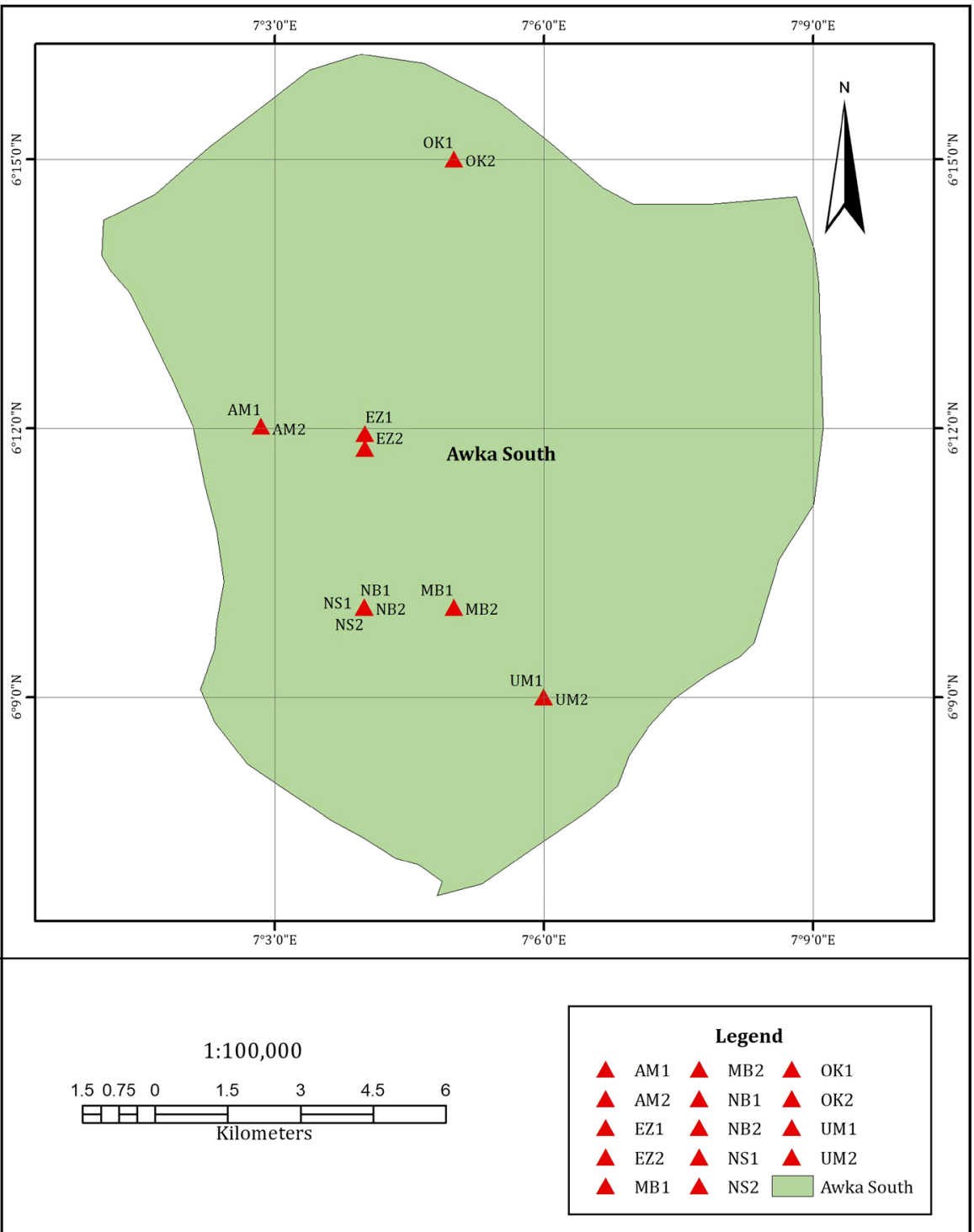

Figure 1. Map of Awka south showing sample locations. 


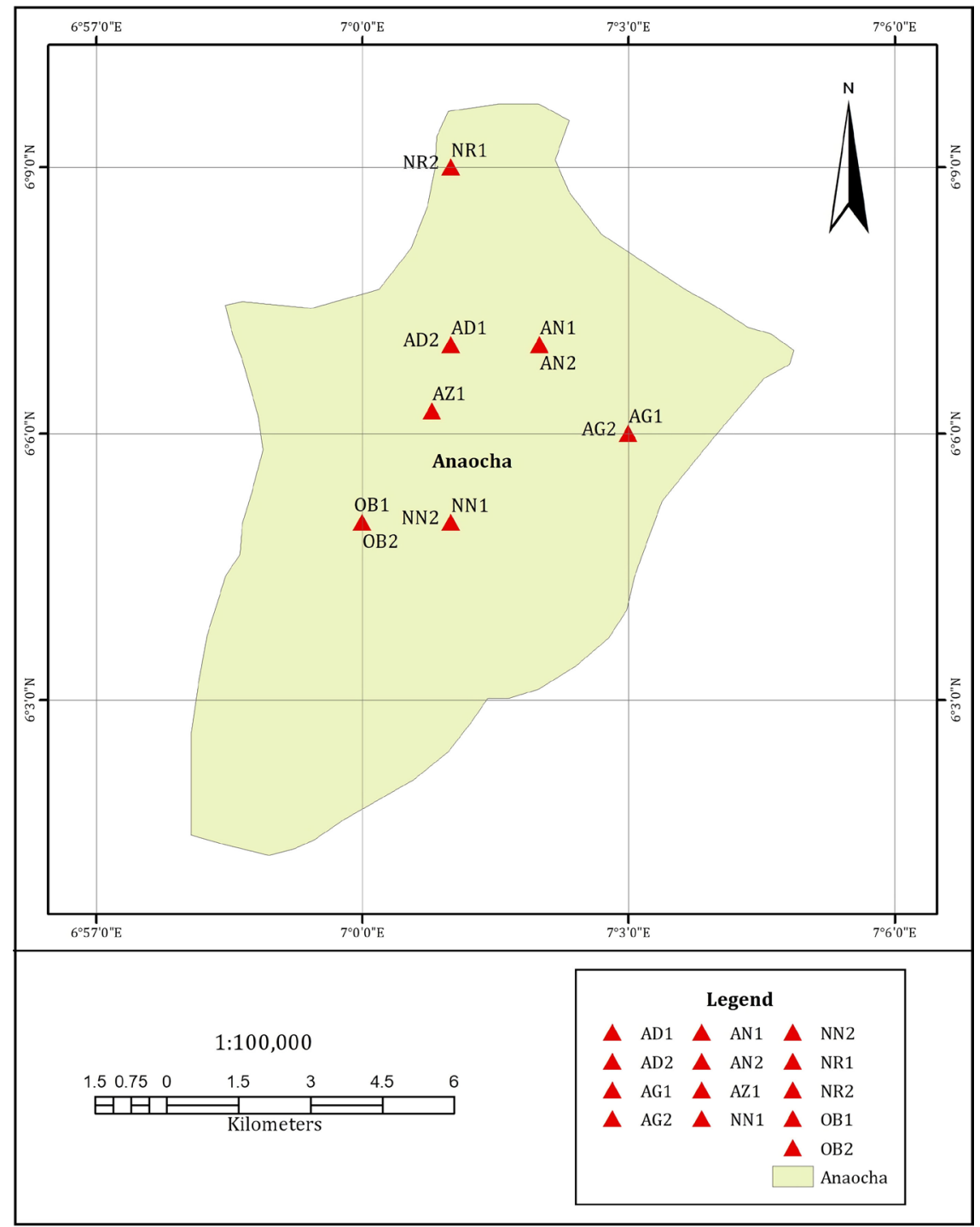

Figure 2. Map of Anaocha showing sample locations.

The samples were tested for $\mathrm{pH}$, Conductivity, Total Hardness, Total Suspended Solids TSS, Lead, Arsenic, Cadmium, Bacteria and Yeast load. All of the drinking water samples were taken from the tap water of residential areas. The samples were collected in a 1-liter polyethylene bottle, which were washed with deionized water. The samples were sealed and placed in a dark environment at temperature of about $15^{\circ} \mathrm{C}$ to avoid effects of temperature and light. For $\mathrm{pH}$, conductivity and Total Suspended Solids TSS, a representative water sampling was carried out from each location and methods of American Public Health Association APHA. The samples were measured using a $\mathrm{pH}$ meter (model HI 96107). The $\mathrm{pH}$ meter was calibrated and standardized with buffer solution for accuracy. The value of each the sample was taking after submerging the probe of the $\mathrm{pH}$ meter in sufficient volume of the water sample to cover the tip of the probe. The $\mathrm{pH}$ reading on the meter was recorded when the reading stabilized. The probe was rinsed with deionized water after each measurement to avoid 


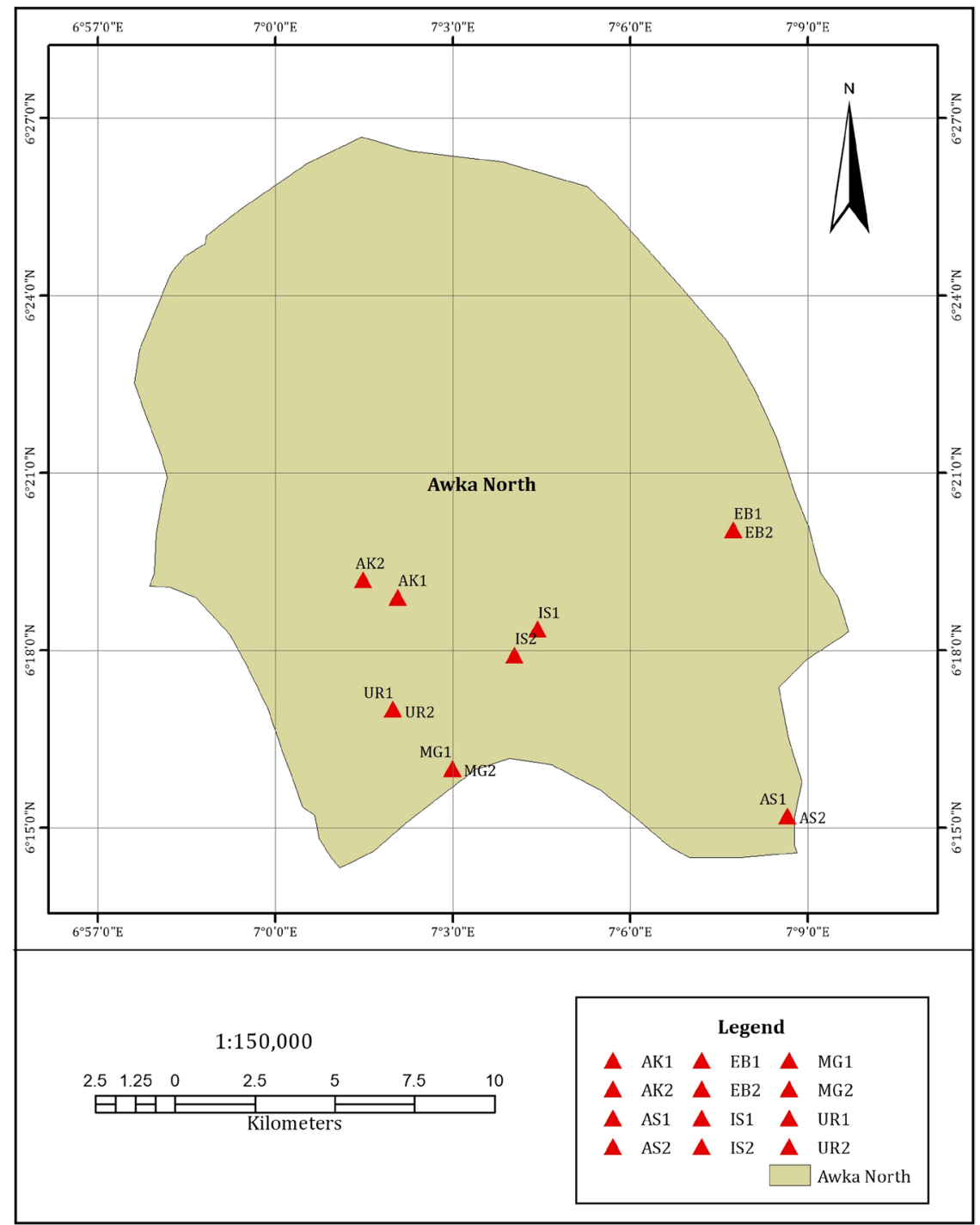

Figure 3. Map of Awka north showing sample locations.

cross contamination of the different samples [59]. The conductivity of the samples was measured using conductivity meter (model DDS 22C) by calibrating the probe of the conductivity meter and standardized. The temperature of the sample was adjusted to $20^{\circ} \mathrm{C} \pm 0.1^{\circ} \mathrm{C}$. The probe was submerged in sufficient volume of the sample. The reading was taken after the disappearance of stability indicator. The probe was rinsed after each measurement to avoid cross contamination [60]. The Total suspended solids TSS of the samples was measured according to standard methods of APHA by filtration process. The Whatman filter paper was dried in an oven to remove the moisture. The filter paper was weighed to obtain the initial weight. $50 \mathrm{~cm}^{3}$ of each of the samples was filtered with the preweighed filter paper. The filter paper was dried and weighed to get the final weight. The total suspended solids in $\mathrm{mg} / \mathrm{L}$ was calculated from the difference in the weights (amount of the suspended solids). Total hardness of the samples was conducted by introducing $50 \mathrm{~cm}^{3}$ of each of the samples into a beaker and adding $1 \mathrm{~cm}^{3}$ of 
buffer solution of ammonia. Three drops of Solochrome Black-T indicator were added and the mixture titrated with 0.01EDTA. The concentrations of two heavy metals: lead, cadmium and a metalloid-arsenic in the water samples were determined using Atomic Absorption Spectrophotometer Varian AA240. The samples were filtered through Whatman $0.45 \mu \mathrm{m}$ membrane filter paper. One hundred milliliters of the filtered water was mixed with $5 \mathrm{~mL}$ concentrated nitric acid $\left(\mathrm{HNO}_{3}\right)$ and $5 \mathrm{~mL}$ concentrated sulphuric acid $\left(\mathrm{H}_{2} \mathrm{SO}_{4}\right)$. To allow the acids to become concentrated, the mixture was heated until the volume was reduced to about 15 to $20 \mathrm{~mL}$. The digested sample was allowed to cool to room temperature. It was then filtered through Whatman's $0.45 \mu \mathrm{m}$ filter paper. The final volume was adjusted to $100 \mathrm{~mL}$ with double distilled water and stored for analysis [61]. The microbiological tests of the samples were carried out by serially diluting the water samples using sterile water up to $10^{-2}$ dilution. $0.1 \mathrm{ml}$ of the diluted water was used to inoculate Nutrient Agar plates all in duplicates, using spread plate method. Nutrient Agar plates were incubated at $37^{\circ} \mathrm{C}$ for 48 hours, while Sabouraud Dextrose Agar plates were incubated at $25^{\circ} \mathrm{C}$ for 5 days. After incubation, the number of colonies in each petri dish was counted, and the number of colony forming unit $(\mathrm{cfu} / \mathrm{ml})$ of the water samples estimated.

\section{Results and Discussions}

The result of the physicochemical analyses (Tables 1-3) showed all the water samples were soft because the values of total hardness were all below WHO Permissible limit of $100 \mathrm{mg} / \mathrm{l}$ [62]. The results of $\mathrm{pH}$ analyses of samples from

Table 1. Physicochemical concentration of water samples from communities in Awka South.

\begin{tabular}{|c|c|c|c|c|c|c|}
\hline Communities & $\mathrm{pH}$ & Conductivity $(\mu \mathrm{S} / \mathrm{cm})$ & TSS (mg/L) & $\mathrm{TH}(\mathrm{mg} / \mathrm{L})$ & $\mathrm{CaH}(\mathrm{mg} / \mathrm{L})$ & $\mathrm{MgH}(\mathrm{mg} / \mathrm{L})$ \\
\hline AM1 & $5.3^{\#}$ & 539.0 & $0.36^{\#}$ & 64 & 36 & 28 \\
\hline AM2 & $5.4^{\#}$ & 204.0 & $0.50^{\#}$ & 54 & 34 & 20 \\
\hline UM1 & $4.5^{\#}$ & 45.1 & $0.44^{\#}$ & 34 & 20 & 14 \\
\hline $\mathrm{UM} 2$ & $4.4^{\#}$ & 16.9 & $0.56^{\#}$ & 54 & 30 & 24 \\
\hline NB1 & $5.2^{\#}$ & 41.6 & $0.68^{\#}$ & 40 & 18 & 22 \\
\hline $\mathrm{NB} 2$ & $5.3^{\#}$ & 40.4 & $0.60^{\#}$ & 58 & 42 & 16 \\
\hline NS1 & $5.6^{\#}$ & 74.7 & $0.60^{\#}$ & 62 & 50 & 12 \\
\hline NS2 & $5.8^{\#}$ & 75.0 & $0.54^{\#}$ & 62 & 50 & 12 \\
\hline MB1 & $4.9^{\#}$ & 157.7 & $0.48^{\#}$ & 36 & 24 & 12 \\
\hline MB2 & $5.4^{\#}$ & 100.7 & $0.44^{\#}$ & 54 & 42 & 12 \\
\hline OK1 & $5.6^{\#}$ & 203.0 & $0.46^{\#}$ & 58 & 40 & 18 \\
\hline $\mathrm{OK} 2$ & $5.6^{\#}$ & 211.0 & $0.64^{\#}$ & 64 & 48 & 16 \\
\hline EZ1 & $5.3^{\#}$ & 158.3 & $0.38^{\#}$ & 60 & 40 & 20 \\
\hline EZ2 & $5.2^{\#}$ & 156.8 & $0.34^{\#}$ & 64 & 56 & 8 \\
\hline
\end{tabular}


Table 2. Physicochemical concentration of water samples from communities in Anaocha.

\begin{tabular}{ccccccc}
\hline Communities & $\mathrm{pH}$ & Conductivity $(\mu \mathrm{S} / \mathrm{cm})$ & $\mathrm{TSS}(\mathrm{mg} / \mathrm{L})$ & $\mathrm{TH}(\mathrm{mg} / \mathrm{L})$ & $\mathrm{CaH}(\mathrm{mg} / \mathrm{L})$ & $\mathrm{MgH}(\mathrm{mg} / \mathrm{L})$ \\
\hline $\mathrm{AD} 1$ & $5.0^{\#}$ & 15.3 & $0.66^{\#}$ & 26 & 18 & 8 \\
$\mathrm{AD} 2$ & $5.4^{\#}$ & 44.7 & $0.52^{\#}$ & 26 & 20 & 6 \\
$\mathrm{AN} 1$ & 6.9 & 61.7 & $0.68^{\#}$ & 54 & 30 & 24 \\
$\mathrm{AN} 2$ & $5.6^{\#}$ & 36.9 & $0.62^{\#}$ & 28 & 18 & 10 \\
$\mathrm{AG} 1$ & $4.6^{\#}$ & 22.4 & $0.40^{\#}$ & 34 & 20 & 14 \\
$\mathrm{AG} 2$ & $5.5^{\#}$ & 37.8 & $0.48^{\#}$ & 28 & 16 & 12 \\
$\mathrm{AZ1}$ & $5.4^{\#}$ & 15.6 & $0.58^{\#}$ & 34 & 22 & 12 \\
$\mathrm{NN} 1$ & $5.5^{\#}$ & 15.5 & $0.46^{\#}$ & 26 & 22 & 4 \\
$\mathrm{NN} 2$ & $6.0^{\#}$ & 17.5 & $0.60^{\#}$ & 14 & 10 & 0.4 \\
$\mathrm{NR} 1$ & $5.0^{\#}$ & 85.2 & $0.54^{\#}$ & 64 & 60 & 0.4 \\
$\mathrm{NR} 2$ & $5.3^{\#}$ & 63.3 & $0.50^{\#}$ & 30 & 24 & 6 \\
$\mathrm{OB} 1$ & $5.4^{\#}$ & 15.4 & $0.42^{\#}$ & 30 & 26 & 4 \\
$\mathrm{OB} 2$ & $5.6^{\#}$ & 27.5 & $0.36^{\#}$ & 30 & 26 & 4 \\
\hline
\end{tabular}

Table 3. Physicochemical concentration of water samples from communities in Awka North.

\begin{tabular}{ccccccc}
\hline Communities & $\mathrm{pH}$ & Conductivity $(\mu \mathrm{S} / \mathrm{cm})$ & TSS $(\mathrm{mg} / \mathrm{L})$ & $\mathrm{TH}(\mathrm{mg} / \mathrm{L})$ & $\mathrm{CaH}(\mathrm{mg} / \mathrm{L})$ & $\mathrm{MgH}(\mathrm{mg} / \mathrm{L})$ \\
\hline AS1 & $6.3^{\#}$ & 32.5 & $0.32^{\#}$ & 46 & 38 & 8 \\
AS2 & $5.4^{\#}$ & 32.3 & $0.22^{\#}$ & 32 & 16 & 10 \\
AK1 & $5.0^{\#}$ & 70.5 & $0.24^{\#}$ & 34 & 18 & 16 \\
AK2 & $6.0^{\#}$ & 34.5 & $0.84^{\#}$ & 44 & 36 & 8 \\
EB1 & $5.0^{\#}$ & 14.6 & $0.14^{\#}$ & 46 & 32 & 14 \\
EB2 & $6.2^{\#}$ & 145.5 & $0.34^{\#}$ & 36 & 24 & 12 \\
UR1 & $5.7^{\#}$ & 69.8 & $2.04^{\#}$ & 48 & 30 & 18 \\
UR2 & $5.0^{\#}$ & 100.6 & $1.60^{\#}$ & 40 & 20 & 18 \\
IS1 & $5.3^{\#}$ & 113.5 & $0.48^{\#}$ & 36 & 22 & 16 \\
IS2 & 6.7 & 101.2 & $1.48^{\#}$ & 38 & 22 & 16 \\
MG1 & $6.4^{\#}$ & 33.8 & $0.44^{\#}$ & 40 & 28 & 12 \\
MG2 & $5.8^{\#}$ & 118.5 & $0.52^{\#}$ & 36 & 26 & 20 \\
\hline
\end{tabular}

"- Not within the permissible limits for $\mathrm{pH} ;{ }^{*}$ - Above the permissible limits for TSS.

communities in Awka South indicated the $\mathrm{pH}$ of all the water samples were all below WHO permissible limit of $6.5-8.5$ [63]. The $\mathrm{pH}$ range and average of samples from the Local Government Area were 4.4 - 5.8 and 5.25 respectively. The results of $\mathrm{pH}$ of samples from communities in Anaocha Local Government Area and Awka North showed that the $\mathrm{pH}$ of all the samples except samples from Bubendof Adazi Nnukwu and Ofiakuz Isuaniocha respectively were below the WHO permissible limit [63] and $\mathrm{pH}$ range/average of samples from the two 
local government areas were 4.6 - 6.9/5.48 and 5.0 - 6.7/5.73 respectively. Generally the water samples from most of the communities in the three Local Government Areas were all acidic, this could be due to corrosion of the water pipes. Also The results of conductivities of the samples from communities from all the three Local Government Areas showed that all the water sample were below the WHO 1993 standard $(250 \mu \mathrm{S} / \mathrm{cm})$ [64] except a sample from Amawbia $(539 \mu \mathrm{S} / \mathrm{cm})$. The conductivities from the Local Government Areas ranged from $16.90-539.00 \mu \mathrm{S} / \mathrm{cm}, 15.3-85.2 \mu \mathrm{S} / \mathrm{cm}$ and $14.6-145.5 \mu \mathrm{S} / \mathrm{cm}$ respectively. The conductivity averages of the three local areas were $144.586 \mu \mathrm{S} / \mathrm{cm}, 35.292 \mu \mathrm{S} / \mathrm{cm}$, $72.275 \mu \mathrm{S} / \mathrm{cm}$ respectively. The low conductivity values could be due to poor and rather insoluble geologic rock and mineral types [65]. Total suspended solids TSS of the water samples from all communities in the three Local Areas were all above NSDWQ standard of $0.01 \mathrm{mg} / \mathrm{L}$ [66] and showed TSS range/average of $0.34-0.68 \mathrm{mg} / \mathrm{L}(0.50 \mathrm{mg} / \mathrm{L}), 0.36-0.68 \mathrm{mg} / \mathrm{L}(0.52 \mathrm{mg} / \mathrm{L})$ and $0.14-2.04 \mathrm{mg} / \mathrm{L}$ $(0.72 \mathrm{mg} / \mathrm{L})$ for Awka South, Anaocha and Awka North respectively.

The result of the elemental analyses (Tables 4-6) showed that the concentrations of lead and arsenic in water samples from communities in Awka South were all above the WHO standard of $0.01 \mathrm{mg} / \mathrm{L}$ [62] [63], except samples from St Joseph Umuawulu, GMG Nibo, Ngodo Nise and St John Nise where lead and arsenic were absent. The range and average concentrations of the lead and arsenic in the samples from the local government area were $0.000-0.103 \mathrm{mg} / \mathrm{L}$ $(0.040 \mathrm{mg} / \mathrm{L})$ and $0.000-2.637(0.850 \mathrm{mg} / \mathrm{L})$ respectively. Lead and arsenic concentrations from communities in Anaocha Local Government Areas were above the WHO standard except sample from Iruowelle Obeledu community where

Table 4. Concentration of $\mathrm{As}^{3+}, \mathrm{Cd}^{2+}, \mathrm{Pb}^{2+}$ in borehole water samples in Awka South $(\mathrm{mg} / \mathrm{L})$.

\begin{tabular}{|c|c|c|c|}
\hline Communities & $\mathrm{As}^{3+}$ & $\mathrm{Cd}^{2+}$ & $\mathrm{Pb}^{2+}$ \\
\hline AM1 & $2.637^{\#}$ & $0.152^{\#}$ & $0.056^{\#}$ \\
\hline AM2 & $0.310^{\#}$ & $0.137^{\#}$ & $0.037^{\#}$ \\
\hline UM1 & $1.032^{\#}$ & $0.136^{\#}$ & $0.068^{\#}$ \\
\hline UM2 & 0.000 & $0.113^{\#}$ & 0.007 \\
\hline NB1 & $0.503^{\#}$ & $0.135^{\#}$ & $0.036^{\#}$ \\
\hline NB2 & 0.000 & $0.112^{\#}$ & 0.000 \\
\hline NS1 & 0.000 & $0.115^{\#}$ & 0.000 \\
\hline NS2 & 0.000 & $0.169^{\#}$ & 0.000 \\
\hline MB1 & $2.059^{\#}$ & $0.136^{\#}$ & $0.044^{\#}$ \\
\hline MB2 & $0.033^{\#}$ & $0.125^{\#}$ & $0.033^{\#}$ \\
\hline OK1 & $1.800^{\#}$ & $0.145^{\#}$ & $0.084^{\#}$ \\
\hline OK2 & $0.011^{\#}$ & $0.135^{\#}$ & $0.022^{\#}$ \\
\hline $\mathrm{EZ1}$ & $1.645^{\#}$ & $0.172^{\#}$ & $0.068^{\#}$ \\
\hline $\mathrm{EZ2}$ & $1.869^{\#}$ & $0.139^{\#}$ & $0.103^{\#}$ \\
\hline
\end{tabular}


Table 5. Concentration of $\mathrm{As}^{3+}, \mathrm{Cd}^{2+}, \mathrm{Pb}^{2+}$ borehole water samples in Anaocha (mg/L).

\begin{tabular}{|c|c|c|c|}
\hline Communities & $\mathrm{As}^{3+}$ & $\mathrm{Cd}^{2+}$ & $\mathrm{Pb}^{2+}$ \\
\hline $\mathrm{AD} 1$ & $1.446^{\#}$ & $0.163^{\#}$ & $0.046^{\#}$ \\
\hline $\mathrm{AD} 2$ & $0.277^{\#}$ & $0.171^{\#}$ & $0.044^{\#}$ \\
\hline AN1 & $2.562^{\#}$ & $0.163^{\#}$ & $0.061^{\#}$ \\
\hline AN2 & $0.652^{\#}$ & $0.147^{\#}$ & $0.069^{\#}$ \\
\hline AG1 & $0.555^{\#}$ & $0.142^{\#}$ & $0.043^{\#}$ \\
\hline AG2 & $2.112^{\#}$ & $0.152^{\#}$ & $0.043^{\#}$ \\
\hline $\mathrm{AZ1}$ & $0.933^{\#}$ & $0.165^{\#}$ & $0.047^{\#}$ \\
\hline NN1 & $1.907^{\#}$ & $0.156^{\#}$ & $0.064^{\#}$ \\
\hline NN2 & 0.00 & $0.146^{\#}$ & $0.077^{\#}$ \\
\hline NR1 & $1.661^{\#}$ & $0.154^{\#}$ & $0.083^{\#}$ \\
\hline NR2 & $1.506^{\#}$ & $0.156^{\#}$ & $0.059^{\#}$ \\
\hline OB1 & $0.515^{\#}$ & $0.172^{\#}$ & $0.100^{\#}$ \\
\hline OB2 & $0.986^{\#}$ & $0.146^{\#}$ & $0.051^{\#}$ \\
\hline
\end{tabular}

Table 6. Concentration of $\mathrm{As}^{3+}, \mathrm{Cd}^{2+}, \mathrm{Pb}^{2+}$ borehole water samples in Awka North $(\mathrm{mg} / \mathrm{L})$.

\begin{tabular}{cccc}
\hline Communities & $\mathrm{As}^{3+}$ & $\mathrm{Cd}^{2+}$ & $\mathrm{Pb}^{2+}$ \\
\hline AS1 & 0.000 & $0.170^{\#}$ & 0.000 \\
AS2 & 0.000 & 0.000 & 0.000 \\
AK1 & 0.000 & $0.434^{\#}$ & 0.000 \\
AK2 & 0.000 & 0.000 & 0.000 \\
EB1 & 0.000 & $0.053^{\#}$ & 0.000 \\
EB2 & 0.000 & 0.000 & 0.000 \\
UR1 & 0.000 & 0.000 & 0.000 \\
UR2 & 0.000 & $0.030^{\#}$ & 0.000 \\
IS1 & 0.000 & 0.000 & 0.000 \\
IS2 & 0.000 & 0.000 & 0.000 \\
MG1 & 0.000 & 0.000 & 0.000 \\
MG2 & 0.000 & $0.004^{\#}$ & 0.000 \\
\hline
\end{tabular}

*- above permissible limits.

the concentration of lead was found to be $0.01 \mathrm{mg} / \mathrm{L}$ and Umueze Neni where arsenic was absent. The concentrations of lead from samples in communities in the two local government areas ranged from $0.100-0.100 \mathrm{mg} / \mathrm{L}$ and the average concentration was found to be $0.061 \mathrm{mg} / \mathrm{L}$. Also the arsenic range and average from samples in communities Anaocha local government area were 0.000 - 2.562 $\mathrm{mg} / \mathrm{L}$ and $1.163 \mathrm{mg} / \mathrm{l}$. The concentration of Arsenic was high in both LGAs could be attributed to the fact that Arsenic is a natural component of the earth's 
crust and so could contaminate the underground water from sources of arsenopyrite, base metal sulfides, realgar and orpiment, arsenic-rich pyrite, and iron oxyhydroxide [67]. The concentrations of cadmium from samples from communities in Awka South and Anaocha were all above the WHO permissible limit of $0.003 \mathrm{mg} / \mathrm{L}$ [62] [63] and ranged from $0.112-0.172 \mathrm{mg} / \mathrm{L}$ and $0.142-0.172$ $\mathrm{mg} / \mathrm{L}$ respectively. The average concentrations of Cadmium in samples from the two LGAs were $0.137 \mathrm{mg} / \mathrm{L}$ and $0.156 \mathrm{mg} / \mathrm{L}$ respectively. Generally, high values of these metals in Awka South and Anaocha could be as a result of some communities in the LGAs being ravaged by erosion menace, indiscriminate siting of industries, blacksmith workshops (major occupation for indigenes of some communities in Awka South), automobile repair workshops etc. Cadmium was absent in many communities in samples from communities in Awka North except samples from Amaeze Amanuke, Igbagu Amansea, Ativ Urum, Uruonaga Mgbakwu, Amagu Ebenebe where the concentrations ranged from $0.004-0.434$ $\mathrm{mg} / \mathrm{L}$. Lead and arsenic were totally absent in samples from Awka North, absence of arsenic could be as a result of presence of Sedimentary rocks tend not to bear high arsenic loads, and common matrices such as sands and sandstones contain lower concentrations owing to the dominance of quartz and feldspars [67]. The absence of lead and very little concentration of cadmium in water samples from Awka North was not surprising because Awka North is the least developed of the three local government areas with least number of industries, batteries from automobile repair workshops, coating, plating, alloys, automobiles, tanks, and broadcasting stations which all use rechargeable storage batteries as the energy source for light [68] [69].

The result of microbiological analyses (Tables 7-9) indicated that the total

Table 7. Microbiology parameters of borehole water samples in Awka South.

\begin{tabular}{ccc}
\hline Communities & Aerobic Bacteria Count $(\mathrm{cfu} / \mathrm{ml})$ & Total Yeast/Mould Count $(\mathrm{cfu} / \mathrm{ml})$ \\
\hline AM1 & $2.48 \times 10^{4 \#}$ & Nil \\
AM2 & $1.22 \times 10^{4 \#}$ & Nil \\
UM1 & $3.4 \times 10^{3 \#}$ & Nil \\
UM2 & $2.7 \times 10^{3 \#}$ & Nil \\
NB1 & $6.5 \times 10^{3 \#}$ & Nil \\
NB2 & $3.1 \times 10^{3 \#}$ & Nil \\
NS1 & $1.01 \times 10^{4 \#}$ & Nil \\
NS2 & $6.3 \times 10^{3 \#}$ & Nil \\
MB1 & $9.7 \times 10^{4 \#}$ & Nil \\
MB2 & $1.08 \times 10^{4 \#}$ & 10 \\
OK1 & $2.03 \times 10^{4 *}$ & 10 \\
OK2 & $4.2 \times 10^{3 \#}$ & Nil \\
EZ1 & $2.22 \times 10^{4 *}$ & $20^{\#}$ \\
EZ2 & $8.7 \times 10^{3 \#}$ & Nil \\
\hline
\end{tabular}


Table 8. Microbiology parameters of borehole water samples in Anaocha.

\begin{tabular}{ccc}
\hline Communities & Aerobic Bacteria Count $(\mathrm{cfu} / \mathrm{ml})$ & Total Yeast/Mould Count $(\mathrm{cfu} / \mathrm{ml})$ \\
\hline AD1 & $3.8 \times 10^{3 \#}$ & Nil \\
AD2 & $7.6 \times 10^{3 \#}$ & Nil \\
AN1 & $3.4 \times 10^{3 \#}$ & Nil \\
AN2 & $4.9 \times 10^{3 \#}$ & Nil \\
AG1 & $3.3 \times 10^{3 \#}$ & Nil \\
AG2 & $1.5 \times 10^{3 \#}$ & Nil \\
AZ1 & $1.05 \times 10^{4 \#}$ & Nil \\
NN1 & $5.0 \times 10^{2}$ & Nil \\
NN2 & $1.1 \times 10^{3 \#}$ & Nil \\
NR1 & $6.4 \times 10^{3 \#}$ & Nil \\
NR2 & $1.2 \times 10^{3 \#}$ & Nil \\
OB1 & $2.24 \times 10^{4 \#}$ & Nil \\
OB2 & $1.36 \times 10^{4 \#}$ & Nil \\
\hline
\end{tabular}

Table 9. Microbiology parameters of borehole water samples in Awka North.

\begin{tabular}{ccc}
\hline Communities & Aerobic Bacteria Count $(\mathrm{cfu} / \mathrm{ml})$ & Total Yeast/Mould Count $(\mathrm{cfu} / \mathrm{ml})$ \\
\hline AS1 & $7.8 \times 10^{3 \#}$ & $90^{\#}$ \\
AS2 & $1.24 \times 10^{4 \#}$ & $60^{\#}$ \\
AK1 & $8.3 \times 10^{3 \#}$ & $40^{\#}$ \\
AK2 & $2.35 \times 10^{4 \#}$ & $\mathrm{Nil}$ \\
EB1 & $8.9 \times 10^{3 \#}$ & 10 \\
EB2 & $1.6 \times 10^{4 *}$ & $120^{\#}$ \\
UR1 & $2.48 \times 10^{4 \#}$ & $\mathrm{Nil}$ \\
UR2 & $2.74 \times 10^{5 *}$ & $30^{\#}$ \\
IS1 & $2.44 \times 10^{4 \#}$ & $209^{\#}$ \\
IS2 & $2.21 \times 10^{4 \#}$ & $\mathrm{Nil}$ \\
MG1 & $2.51 \times 10^{4 \#}$ & 10 \\
MG2 & $2.84 \times 10^{4 \#}$ & $\mathrm{Nil}$ \\
\hline
\end{tabular}

*- Above permissible limits.

aerobic bacteria count of samples from communities in Awka South were all above permissible limits of WHO [64] of $1.0 \times 10^{3} \mathrm{cfu} / \mathrm{ml}$. The values ranged 2.7 $\times 10^{3}-9.7 \times 10^{4} \mathrm{cfu} / \mathrm{ml}$. Total aerobic bacterial count of sample from communities in Anaocha were above the permissible limit except sample from Umueri Neni which was $5.0 \times 10^{2} \mathrm{cfu} / \mathrm{ml}$. The values from the LGAs ranged from $5.0 \times$ $10^{2}-2.24 \times 10^{4} \mathrm{cfu} / \mathrm{ml}$. Results of the microbial load of samples from Awka North also showed that they were all above the permissible standard and ranged from $7.8 \times 10^{3}-2.74 \times 10^{5} \mathrm{cfu} / \mathrm{ml}$. Yeast load did not pose any threat in samples 
from communities in Anaocha where yeasts were found to be absent. They did not pose much threats in samples from communities from Awka South where they were only present in little amounts in three locations: Akabor Mbaukwu, $\mathrm{Y}$ junction Okpuno, Ndikpa Ezinato with values $10 \mathrm{cfu} / \mathrm{ml}, 10 \mathrm{cfu} / \mathrm{ml}, 20 \mathrm{cfu} / \mathrm{ml}$ respectively. The yeast load of samples from Awka North also posed some threats where the total yeast counts were present except in Eziama Amanuke, Umuife Urum, Ofiakuz Isuaniocha, Uruonage Mgbakwu they were absent. The total yeast load ranged from $10 \mathrm{cfu} / \mathrm{ml}-209 \mathrm{cfu} / \mathrm{ml}$. According to Desrosier and Singh 2018, the pH range for yeast growth is 3.5 - 4.5 and for molds is $3.5-8.0$. Yeasts are unable to grow at a water activity of less than 0.9 , and molds are unable to grow at a water activity below 0.8 . The low $\mathrm{pH}$ of fruits is generally unfavourable for the growth of bacteria [70]. It was expected that considering the acidity of the water samples in all the LGAs, the yeast load would be high and the bacterial load low, but reverse was the case. The high value of aerobic bacterial count in all the samples was expected because in most communities in Anambra State, pit latrines and open defecation are still being practiced. Generally, the total aerobic bacteria count and yeast load counts of samples from Awka North were highest and could be attributed to highest rate of open defecation and use of pit latrines practices in many communities in the Local Government Area.

\section{Conclusion}

Availability of quality potable water is key to achieving sustainable public health which is an important goal of the United Nations. Dwindling municipal water supply leads to water and sanitation crisis. For their domestic needs, people fall back on dubious water sources, many of which contain dangerous contaminants. Since they cannot afford the high expense of water treatment, people helplessly take the contaminated water [71]. The results showed "potable" water samples that were acidic, highly polluted with metals and microbial loads. Since all aspects of social, economic and health development of any people or place depend on water, absence of quality potable municipal water supply in Anambra State calls to question of the social, economic, health development and the life of the residents of the State.

\section{Conflicts of Interest}

The authors declare that there is no conflict of interests regarding the publication of this paper.

\section{References}

[1] Food and Agriculture Organization of the United Nations Rome (2012) Coping with Water Scarcity: An Action Framework for Agriculture and Food Security. FAO Water Reports 38.

[2] Akpan-Idiok, A.U., Ibrahim, A. and Udo, I.A. (2012) Water Quality Assessment of Okpauku River for Drinking and Irrigation Uses in Yala, Cross River State, Nigeria. 
Research Journal of Environmental Sciences, 6, 210-221. https://doi.org/10.3923/rjes.2012.210.221

[3] Akpe, A. (2011) Many Leaks Yearning for Plugs in Nigeria's Water Sector, Business Day.

[4] Adeniran, A. (2018) Assessment of Water Quality in Slum Area Ibadan. Hydrology. Current Research, 9, 296. https://doi.org/10.4172/2157-7587.1000296

[5] Rout, C. and Sharma, A. (2011) Assessment of Drinking Water Quality: A Case Study of Ambala Cantonment Area, Haryana, India. International Journal of Environmental Sciences, 2, 933-945.

[6] Eseigbe, A.P., Ibhadode, O., Ayoola, A.R. and Sosanolu, O.M. (2018) Experimental Determination of Drinking Water Quality in Abeokuta Metropolis, South-Western Nigeria. International Journal of Advances in Scientific Research and Engineering, 4, 241-256. https://doi.org/10.31695/IJASRE.2018.33035

[7] Hutton, G. and Chase, C. (2017) Water Supply, Sanitation, and Hygiene. In: Mock, C.N., Nugent, R., Kobusingye, O. and Smith, K., Eds., Disease Control Priorities (Third Edition): Volume 7, Injury Prevention and Environmental Health, World Bank, Washington DC. https://doi.org/10.1596/978-1-4648-0522-6 ch9

[8] Mena-Rivera, L. and Quirós-Vega, J. (2018) Assessment of Drinking Water Suitability in Low Income Rural Areas. Journal of Water and Health, 16, 403-413. https://doi.org/10.2166/wh.2018.203

[9] Dinka, M.O. (2018) Safe Drinking Water: Concepts, Benefits, Principles and Standards. In: Glavan, M., Ed., Water Challenges of an Urbanizing World, IntechOpen, London, 163-181. https://doi.org/10.5772/intechopen.71352

[10] UN Water (2007) World Water Day. Coping with Water Scarcity, Challenge of the Twenty-First Century.

[11] Moe, C.L. and Rheingans, R.D. (2006) Global Challenges in Water, Sanitation and Health. Journal of Water and Health, 4, 41-57. https://doi.org/10.2166/wh.2006.0043

[12] Ohwo, O. and Abotutu, A. (2014) Access to Potable Water Supply in Nigerian Cities Evidence from Yenagoa Metropolis. American Journal of Water Resources, 2, 31-36. https://doi.org/10.12691/ajwr-2-2-1

[13] Curry, E. (2010) Water Scarcity and the Recognition of the Human Right to Safe Freshwater. Northwestern Journal of Human Rights, 9, 103. http://scholarlycommons.law.northwestern.edu/njihr/vol9/iss1/5D

[14] UN-HABITAT, Water and Sanitation (2013) Programmes: Water and Sanitation.

[15] Gray, F.N. (2014) Pathogen Control in Drinking Water. In: Percival, L.S. and Yates V.M., Eds., Microbiology of Waterborne Diseases, 2nd Edition, Elsevier, Oxford, Volume 1, 537-570. https://doi.org/10.1016/B978-0-12-415846-7.00030-5

[16] Levallois, P. and Villanueva, C.M. (2019) Drinking Water Quality and Human Health: An Editorial. International Journal of Environmental Research and Public Health, 16, 631. https://doi.org/10.3390/ijerph16040631

[17] WHO/UNICEF Joint Monitoring Programme (2015) Progress on Drinking Water, Sanitation and Hygiene: Update and MDG Assessment. WHO Press, Geneva, New York.

[18] Guppy, L. and Anderson, K. (2017) Water Crisis Report. United Nations University Institute for Water, Environment and Health, Hamilton.

[19] WHO/UNICEF Joint Monitoring Programme 2017 Report. Progress on Drinking 
Water, Sanitation and Hygiene 2017 Update and SDG Baseline.

[20] WHO/UNICEF Joint Monitoring Programme 2019 Report. Progress on Drinking Water, Sanitation and Hygiene: 200-2017: Special Focus on Inequalities, New York/Geneva.

[21] Kumpel, E., Delaire, C., Peletz, R., Kisiangani, J., Rinehol, A., De France, J., Sutherland, D. and Khush, R. (2018) Measuring the Impacts of Water Safety Plans in the Asia-Pacific Region. International Journal of Environmental Research and Public Health, 15, 1223. https://doi.org/10.3390/ijerph15061223

[22] United Nations Development of Economic and Social Affairs UNDESA, International Decade for Action "Water for Life" 2005-2015. Resolution A/ERS/58/217. http://www.un.org/waterforlifedecade

[23] Robinson, D.T., Schertenleib, A., Kunwar, B.M., Shrestha, R., Bhatta, M. and Marks, S.J. (2018) Assessing the Impact of a Risk-Based Intervention on Piped Water Quality in Rural Communities: The Case of Mid-Western Nepal. International Journal of Environmental Research and Public Health, 15, 1616. https://doi.org/10.3390/ijerph15081616

[24] Moropeng, R.C., Budeli, P., Mpenyana-Monyatsi, L. and Momba, M.N.B. (2018) Dramatic Reduction in Diarrhoeal Diseases through Implementation of Cost-Effective Household Drinking Water Treatment Systems in Makwane Village, Limpopo Province, South Africa. International Journal of Environmental Research and Public Health, 15, 410. https://doi.org/10.3390/ijerph15030410

[25] Naik, P.K. (2016) Water Crisis in Africa: Myth or Reality? International Journal of Water Resources Development, 33, 326-339. https://doi.org/10.1080/07900627.2016.1188266

[26] Awuah, E., Nyarko, K.B., Owusu, P.A. and Osei-Bonsu, K. (2009) Small Town Water Quality. Desalination, 248, 453-459. https://doi.org/10.1016/j.desal.2008.05.087

[27] World Health Organization (2015) WHO World Water Day Report. http://www.who.int/water sanitation health/takingcharge.html

[28] Osunla, C.A. and Okoh, A.I. (2017) Review Vibrio Pathogens: A Public Health Concern in Rural Water Resources in Sub-Saharan Africa. International Journal of Environmental Research and Public Health, 14, 1188. https://doi.org/10.3390/ijerph14101188

[29] Adeleye, B., Medayese, S. and Okelola, O. (2014) Problems of Water Supply and Sanitation in Kpakungu Area of Minna (Nigeria). Glocalism: Journal of Culture, Politics and Innovation, 1-2.

[30] Mukuhlani, T. and Nyamupingidza, M.T.I. (2014) Water Scarcity in Communities, Coping Strategies and Mitigation. Measures: The Case of Bulawayo. Journal of Sustainable Development, 7, 144-160. https://doi.org/10.5539/jsd.v7n1p144

[31] Alexander, W. (2008) Address Presented at Sharm El-Sheik, Egypt Africa San 2008. Conference of African Union, June 30.

[32] The Millennium Project 2018, Global Challenge 2. How Can Everyone Have Sufficient Clean Water without Conflict?

[33] Muta'a Hellandendu, J. (2012) Health Implications of Water Scarcity in Nigeria. European Scientific Journal, 8, 111-117.

[34] Ocheri, M.I., Odoma, L.A. and Umar, N.D. (2014) Groundwater Quality in Nigerian Urban Areas: A Review. Global Journal of Science Frontier Research, 14, 35-46.

[35] He, Z., Bishwajit, G., Zou, D., Yaya, S., Cheng, Z. and Zhou, Y. (2018) Burden of Common Childhood Diseases in Relation to Improved Water, Sanitation, and Hy- 
giene (WASH). International Journal of Environmental Research and Public Health, 15, 1241. https://doi.org/10.3390/ijerph15061241

[36] Alinejad, A., Farsani, S.F., Bahmani, Z., Barafrashtehpour, M., Sarsangi, V., Khodadadi, R., Conti, G.O., Golmohammadi, S., Moradi, B. and Fakhri, Y. (2016) Evaluation of Heavy Metals Level (Arsenic, Nickel, Mercury and Lead) Effecting on Health in Drinking Water Resource of Kohgiluyeh County Using Geographic Information System (GIS). International Journal of Medical Research \& Health Sciences, 5, 233-241.

[37] Kolawole, O.M., Ajayi, K.T., Olayemi, A.B. and Okoh, A.I. (2011) Assessment of Water Quality in Asa River (Nigeria) and Its Indigenous Clarias gariepinus Fish. International Journal of Environmental Research and Public Health, 8, 4332-4352. https://doi.org/10.3390/ijerph8114332

[38] Wodschowi, K., Hansen, B., Schullehner, J. and Ersbøll, A.K. (2018) Stability of Major Geogenic Cations in Drinking Water-An Issue of Public Health Importance: A Danish Study, 1980-2017. International Journal of Environmental Research and Public Health, 15, 1212. https://doi.org/10.3390/ijerph15061212

[39] Grumbles, B. (2009) Sustaining Progress for Clean and Safe Water. Global Environmental Health: Research Gaps and Barriers for Providing Sustainable Water, Sanitation, and Hygiene Services. http://www.nap.edu/catalog/12597.html

[40] Abedin, M.A., Collins, A.E., Habiba, U. and Shaw, R. (2019) Climate Change, Water Scarcity, and Health Adaptation in Southwestern Coastal Bangladesh. International Journal of Disaster Risk Science, 10, 28-42. https://doi.org/10.1007/s13753-018-0211-8

[41] Pearson, A.L., Mayer, J.D. and Bradley, D.J. (2015) Coping with Household Water Scarcity in the Savannah Today: Implications for Health and Climate Change into the Future. Earth Interactions, 19, 1-14. https://doi.org/10.1175/EI-D-14-0039.1

[42] Babič, M.N., Gunde-Cimerman, N., Vargha, M., Magyar, Z.T.D., Veríssimo, C., Sabino, R., Viegas, C., Meyer, W. and Brandão, J. (2017) Fungal Contaminants in Drinking Water Regulation? A Tale of Ecology, Exposure, Purification and Clinical Relevance. International Journal of Environmental Research and Public Health, 14, 636. https://doi.org/10.3390/ijerph14060636

[43] Babic, M.N., Zalara, P., Zenko, B., Dzeroski, S. and Gunde-Cimerman, N. (2015) Yeasts and Yeast-Like Fungi in Tap Water and Groundwater, and Their Transmission to Household Appliances. Fungal Ecology, 20, 30-39.

https://doi.org/10.1016/j.funeco.2015.10.001

[44] Ayanbimpe, G.M., Abbah, V.E. and Ior, C.A. (2012) Yeasts and Yeast-Like Fungal Contaminants of Water Used for Domestic Purposes in Jos, Nigeria. Microbiology Research, 3, 99-102. https://doi.org/10.4081/mr.2012.e24

[45] Chaminuka, L. and Nyatsanza, T.D. (2013) An Assessment of Water Shortages and Coping Mechanisms of Harare Residents: A Case of Msasa Park and Dzivaresekwa Extension. IOSR Journal of Agriculture and Veterinary Science, 4, 21-35. https://doi.org/10.9790/2380-0432135

[46] Kandji, S. (2006) Drought in Kenya: Climatic, Economic and Socio-Political Factors. New Standpoints (November-December), 17-19.

[47] Jidauna, G.G., Barde, S.R., Ndabula, C., Oche, C.Y. and Dabi, D.D. (2017) Water Quality Assessment of Selected Domestic Water Sources in Dutsinma Town, Katsina State. Science World Journal, 12, 43-50.

[48] Ishaku, H.T., Rafee Majid, M., Ajayi, A.P. and Haruna, A. (2011) Water Supply Dilemma in Nigerian Rural Communities: Looking towards the Sky for an Answer. 
Journal of Water Resource and Protection, 3, 598-606. https://doi.org/10.4236/jwarp.2011.38069

[49] Ohwo, O. and Abotutu, A. (2014) Access to Potable Water Supply in Nigerian Cities Evidence from Yenagoa Metropolis. American Journal of Water Resources, 2, 31-36. https://doi.org/10.12691/ajwr-2-2-1

[50] Deldar, A.N. and Abedi, M. (2017) Determination of Heavy Metals (Cadmium, Arsenic and Lead) in Iranian, Pakistani and Indian Rice Consumed in Khorasan-Razavi Province, Iran by Inductively Coupled Plasma (ICP). International Journal of Scientific Study, 5, 534-536

[51] Hutton, M. (1987) Lead, Mercury, Cadmium and Arsenic in the Environment, Human Health Concerns of Lead, Mercury, Cadmium and Arsenic. SCOPE. John Wiley \& Sons Ltd., Hoboken, 53-68. https://doi.org/10.1016/0048-9697(88)90384-1

[52] Chowdhury, R., Ramond, A., O’Keeffe, L.M., Shahzad, S., Kunutsor, S.K., Muka, T., Gregson, J., Willeit, P., Warnakula, S., Khan, H., Chowdhury, S., Gobin, R., Franco, O.H. and Di Angelantonio, E. (2018) Environmental Toxic Metal Contaminants and Risk of Cardiovascular Disease: Systematic Review and Meta-Analysis. BMJ, 362, k3310. https://doi.org/10.1136/bmj.k3310

[53] Ezenwaji, E.E., Awopeju, A.K., Otti, V.I. and Eduputa, B.M. (2014) Spatial Patterns of Residential Water Supply Accessibility Levels in Anambra State, Nigeria. International Journal of Engineering Research and Applications, 4, 326-336.

[54] Chinweze, C. (2017) IAIA17 Conference Proceedings|IA's Contribution in Addressing Climate Change. 37 th Annual Conference of the International Association for Impact Assessment, Le Centre Sheraton, Montréal, Canada, 4-7 April 2017. http://www.iaia.org/

[55] Obiadi, I.I., Nwosu, C.M., Ajaegwu, N.E., Anakwuba, E.K., Onuigbo, N.E., Akpunonu, E.O. and Ezim, O.E. (2011) Gully Erosion in Anambra State, South East Nigeria: Issues and Solution. International Journal of Environmental Sciences, 2, 795-804.

[56] Ojiako, J.C., Igbokwe, E.C. and Ugwumba, R.J. (2018) Analysis of Land Use Dynamics of Awka South L.G.A Using Remote Sensing and Geographic Information System. IOSR Journal of Environmental Science, Toxicology and Food Technology, 12, 67-72. http://www.iosrjournals.org

[57] Azuike, E.C., Nwabueze, S.A., Onyemachi, P.E., Egenti, B.N., Okafor, K.C., Aniemena, R.C., Udedibia, I.N. and Nwodo, J.O. (2015) Household Waste Management; Voices of Residents of Anaocha Local Government Area of Anambra State, Nigeria. Journal of Environmental Protection, 6, 1394-1401. https://doi.org/10.4236/jep.2015.612121 http://www.scirp.org/journal/jep

[58] Nse-Nelson, F.A., Osondu, K.R., Oke, U.R. and Chux, J.C. (2017) Economic Analysis of Beef Marketing in Awka North Local Government Area of Anambra State, Nigeria. Agro-Science, 16, 9-14. https://doi.org/10.4314/as.v16i3.2

[59] Rahmanian, N., Bt Ali, S.H., Homayoonfard, M., Ali, N.J., Rehan, M., Sadef, Y. and Nizami, S. (2015) Analysis of Physiochemical Parameters to Evaluate the Drinking Water Quality in the State of Perak, Malaysia. Journal of Chemistry, 2015, Article ID: 716125. https://doi.org/10.1155/2015/716125

[60] UNEP/WHO (1996) Water Quality Monitoring: A Practical Guide to the Design and Implementation of Freshwater Quality Studies and Monitoring Programmes.

[61] Cobbina, S.J., Duwiejuah, A.B., Quansah, R., Obiri, S. and Bakobie, N. (2015) Comparative Assessment of Heavy Metals in Drinking Water Sources in Two 
Small-Scale Mining Communities in Northern Ghana. International Journal of Environmental Research and Public Health, 12, 10620-10634. https://doi.org/10.3390/ijerph120910620

[62] WHO (2008) Guidelines for Drinking-Water Quality [Electronic Resource]: Incorporating 1st and 2nd Addenda, Vol. 1, Recommendations. 3rd Edition, WHO Library Cataloguing-in-Publication Data. Geneva.

[63] WHO (2011) Guidelines for Drinking-Water Quality. 4th Edition, WHO Library Cataloguing-in-Publication Data.

[64] WHO Geneva (1993) Guidelines for Drinking-Water Quality. 2nd Edition, Contents: V. 1. Recommendations. WHO Library Cataloguing in Publication Data.

[65] Oyem, H.H., Oyem, I.M. and Ezeweali, D. (2014) Temperature, pH, Electrical Conductivity, Total Dissolved Solids and Chemical Oxygen Demand of Groundwater in Boji-Boji Agbor/Owa Area and Immediate Suburbs. Research Journal of Environmental Sciences, 8, 444-450. https://doi.org/10.3923/rjes.2014.444.450 https://scialert.net/abstract/?doi=rjes.2014.444.450

[66] Ugbaja, A.N. and Ephraim, B.E. (2018) Physicochemical and Bacteriological Parameters of Surface Water Quality in Part of Oban Massif, Nigeria. Global Journal of Geological Sciences, 17, 13-24. https://doi.org/10.4314/gjgs.v17i1.2

[67] Garelick, H., Jones, H., Dybowska, A. and Valsami-Jones, E. (2008) Arsenic Pollution Sources. Reviews of Environmental Contamination and Toxicology, 197, 17-60. https://doi.org/10.1007/978-0-387-79284-2 2

[68] Sharma, H., Rawal, N. and Mathew, B. (2015) The Characteristics, Toxicity and Effects of Cadmium. International Journal of Nanotechnology and Nanoscience, 3 , $1-9$.

[69] Zhang, R., Wilson, V., Hou, A. and Meng, G. (2015) Source of Lead Pollution, Its Influence on Public Health and the Countermeasures. International Journal of Health, Animal Science \& Food Safety, 2, 18-31.

[70] Desrosier, N.W. and Singh, R.P. (2018) Food Preservation. Encyclopædia Britannica, Inc., Chicago. https://www.britannica.com/topic/food-preservation

[71] Eneh, O.C. (2011) Effects of Water and Sanitation Crisis on Infants and Under-Five Children in Africa. Journal of Environmental Science and Technology, 4, 103-111. https://scialert.net/abstract/?doi=jest.2011.103.111 https://doi.org/10.3923/jest.2011.103.111 